\title{
The Growth of "Localism" in Hong Kong
}

A New Path for the Democracy Movement?

\section{Ying-ho Kwong}

\section{(2) OpenEdition}

\section{Journals}

Electronic version

URL: http://journals.openedition.org/chinaperspectives/7057

DOI: 10.4000/chinaperspectives.7057

ISSN: 1996-4617

\section{Publisher}

Centre d'étude français sur la Chine contemporaine

\section{Printed version}

Date of publication: 1 September 2016

Number of pages: 63-68

ISSN: 2070-3449

\section{Electronic reference}

Ying-ho Kwong, "The Growth of "Localism" in Hong Kong », China Perspectives [Online], 2016/3 | 2016, Online since 01 September 2016, connection on 14 September 2020. URL : http://

journals.openedition.org/chinaperspectives/7057

(C) All rights reserved 


\title{
The Growth of "Localism"
}

\section{in Hong Kong}

\author{
A New Path for the Democracy Movement?
}

\section{YING-HO KWONG}

A series of political protests in recent years, including localist rallies for the June 4 Massacre, anti-parallel trading protests, and the Mong Kok Riot, have triggered concerns over the development of "localism" (bentu zhuyi 本土主義) in Hong Kong. For decades, traditional pan-democratic parties (fan minzhupai 泛民主派) have been struggling with the Chinese government over political development. Although many of them have persistently bargained with the Beijing leaders, progress towards democracy remains stagnant. Thus, Hong Kong's democrats have been beset by "transition fatigue," which commonly exists in hybrid regimes that combine both democratic and authoritarian elements. ${ }^{(1)}$ A growing number of Hong Kong people, especially youngsters, have become impatient, disappointed, and sceptical towards the existing pan-democratic parties, and have shifted into the localist camp in order to search for new direction against political intervention by China.

Localism, according to Law Wing-sang, refers to a political movement that focuses on the preservation of Hong Kong's identity and autonomy. ${ }^{(2)}$ The movement includes a multitude of groups with different goals, ranging from advocating greater autonomy to independence for Hong Kong, but most of them have developed a strong sense of local identity and object to growing political encroachment by the Beijing government into Hong Kong's political, economic, and social affairs. The rise of localism that has adopted strong "anti-China" positions implies more confrontation within the democracy camp overall. Thus, the democracy movement in Hong Kong has entered a new stage, with a more polarised democratic scene. Existing literature has long recognised that the traditional pan-democratic camp has been serving an important political function of promoting democratic development. ${ }^{(3)}$ However, the implications of the newly established localist groups have yet to be thoroughly explored. By studying the gradual rise of "localism," this article attempts to examine why there has been an increase in localist groups, what impact this will have on the democratic camp as a whole, and how the authorities have responded.

\section{"Transition fatigue" in Hong Kong}

The existence of a traditional pan-democratic camp in Hong Kong can be traced back to the negotiations for democracy in Hong Kong since the middle of the 1980s. At that time, Martin Lee and Szeto Wah, two democrats who led a pro-democratic alliance with 95 groups, were invited to take part in the Drafting Committee to design the Basic Law, the "mini-constitution" after the handover. Although Beijing had no intention of providing any concrete promises such as full democracy, the democrats largely agreed to maintain harmonious relations, and supported the reversion of sovereignty from Britain to China after 1997 under the principle of "One Country, Two Systems." (4) In fact, Hong Kong's democrats have always been divided by ideological differences, but have sought room for co-operation on political issues. The collaboration among democrats strengthened during and after the Tiananmen Massacre. During the 1989 democracy movement in China, Hong Kong democrats formed the Hong Kong Alliance in Support of Patriotic Democratic Movements in China to support the Beijing protesters. In the meantime, disagreements among democrats generally decreased because the majority shared the common goal of supporting democratic development in China against the bloody clampdown by the authorities. ${ }^{(5)}$

The wave of democracy movements further intensified after 1997. In the early stage after the handover, the democrats were still working together to fight against political control by Beijing. This sentiment kept rising until 2003, when the Hong Kong Special Administrative Region (HKSAR) government decided to enact the national security law (Article 23) in the Legislative Council, an anti-subversion law intended to constrain political rights, resulting in 500,000 people marching on 1 July. Although the bill was finally withdrawn by the government, this biggest march after the handover provoked Beijing leaders to start intervening in Hong Kong affairs. After this incident, the democrats repeatedly organised huge rallies calling for full universal suffrage to elect the Chief Executive and Legislative Council in 2007 and 2008, respectively. In contrast, Beijing's response was highly hostile and criticised the democrats as attempting to destabilise Hong Kong. ${ }^{(6)}$

However, by 2008, "transition fatigue" existed among pan-democrats. Some studies in hybrid regimes predict that a long period of political stagnation contributes to rising discontent regarding the status quo and attrib-

1. Ngok Ma, "Hong Kong's Democrats Divide," Journal of Democracy, Vol. 22, No. 1, 2011, pp. 54-67.

2. Wing-sang Law, "Xianggang bentu yundong de xingqi yu zhuanzhe" (The trajectories of Hong Kong localist movement), Taiwan Literature Studies, No. 4, 2013, p. 96.

3. Jermain T.M. Lam, The Political Dynamics of Hong Kong Under Chinese Sovereignty, New York, Nova Science Publishers, Inc., 2000; Ngok Ma, Political Development in Hong Kong: State, Political Society and Civil Society, Hong Kong, Hong Kong University Press, 2007; Baohui Zhang, "Political Paralysis of the Basic Law Regime and the Politics of Institutional Reform in Hong Kong," Asian Survey, Vol. 49, No. 2, 2009, pp. 312-332; Ming Sing, "Hong Kong's Democrats Hold their Own," Journal of Democracy, Vol. 20, No. 1, 2009, pp. 98-112.

4. Sonny Shiu-hing Lo, "The Role of a Political Interest Group in Democratization of China and Hong Kong: The Hong Kong Alliance in Support of Patriotic Democratic Movements of China," Journal of Contemporary China, Vol. 22, No. 83, pp. 923-943.

5. Joseph Y. S. Cheng, "The Tiananmen Incident and the Pro-democracy Movement in Hong Kong," China Perspectives, No. 2009/2, pp. 91-100.

6. Wai-man Lam and Irene L. K. Tong, "Civil Society and NCOs," in Wai-man Lam, Percy Luen-tim Lui, Wilson Wong, and lan Holliday (eds), Contemporary Hong Kong Politics: Governance in the Post-1997 Era, Hong Kong, Hong Kong University Press, 2007, pp. 135-154. 
Graph 1 - Development of public discourse on the "localist camp" from 2007 to May 2016

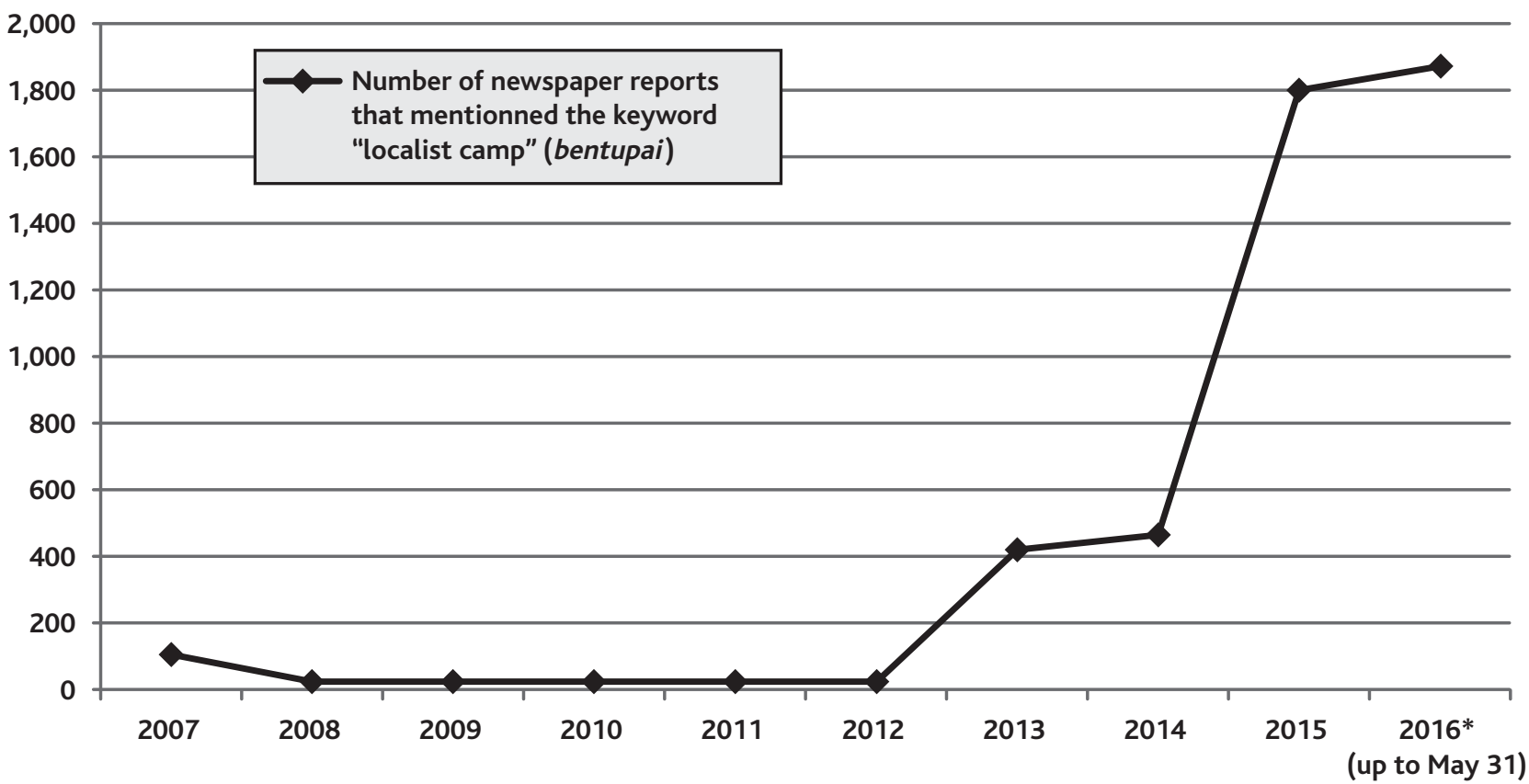

Source: author's own research, based on information received from the WieseNews electronic platform. The research counted the number of newspaper reports that mentioned "localist camp" (bentupai 本土派) between 2007 and May 2016. The local newspapers covered in this research are Apple Daily, Hong Kong Commercial Daily, Hong Kong Economic Journal, Hong Kong Economic Times, Ming Pao Daily News, Oriental Daily News, Sing Pao, Sing Tao Daily, Ta Kung Pao, and Wen Wei Po.

utes responsibility to both the government and leaders of the opposition camp. ${ }^{(7)}$ Hong Kong democrats face a long struggle in the face of Beijing's desire for democratic display without substance. The Legislative Council election in 2008 was marked by some democrats starting to urge the adoption of a more progressive approach to pressure the authorities to make political reforms. The League of Social Democrats (LSD), a relatively radical party, proposed a "de facto referendum." Their idea was for five out of 23 pan-democratic legislators, one from each of the five Legislative Council districts, to resign at the same time, and called for the result of by-elections to be viewed as a popular referendum on democracy. The Civic Party (CP), led by professionals and the middle class, agreed to this action, but the Democratic Party (DP), the leading opposition party, refused. The DP feared that the resignations would antagonise moderate voters and infuriate the Chinese government. Although the CP-LSD alliance won their seats back, many democrats strongly criticised the rejection by the DP, and the political rift within the democracy camp deepened. (8)

The divide among Hong Kong's democrats increased drastically when the DP decided to "bargain" with Chinese leaders over the political reform package. Direct face-to-face negotiations between Beijing leaders and DP legislators were held in May 2010. After the discussion, DP chairman Albert Ho publicly stated that he would urge party members to support the political reform package when the government agreed to expand the franchise behind the five new functional constituency seats to include Hong Kong's 3.2 million voters. Leaders of the LSD adamantly accused the DP of reaching "secret deals" with the Beijing leaders and of "betraying" the democracy movement. ${ }^{(9)}$

Following passage of the political reform package, the rift between moderate and radical democrats grew wider. More and more pan-democratic supporters were increasingly disappointed with the DP's decision and shifted their support to "radical resistance." In 2011, People Power, a radical group led by former LSD chairman Wong Yuk-man, advocated a "Vote-them Out Campaign" to "punish" the DP in the District Council elections. They also advocated infusing new resistance strategies such as filibustering and occupying events to push the government to make political reforms. More hard-line democrats were convinced that a more "radical" strategy should be used to challenge "Hong Kong Communists ruling Hong Kong" and to defend Hong Kong against the control of the Beijing government. More importantly, they believed that pan-democrats were too conservative and hindered the democratic movement. Their advocacy was highly controversial at that time but incrementally changed the political culture in Hong Kong, indirectly cultivating the rise of localism.

\section{The rise of localism}

Growing dissatisfaction with the established opposition pan-democracy camp's efforts to challenge the existing political system has led many Hong Kong people to consider a new direction to protect the interests of Hong Kong. This is one of the key factors that has nurtured the rise of the localist movement. In recent years, "localist camp" has become one of the most popular terms used by local politicians and the media to describe politics in Hong Kong (see Graph 1). Originally, the roots of localism were not political. The first wave emerged in 2005 when activists set up groups such as Local Action to campaign to protect the Star Ferry Pier and Queen's Pier from demolition. By preserving Hong Kong history, these movements led to a reflection on Hong Kong's political identity.

Indeed, localism has taken on a political dimension over the past few years with the growing tendency of Hong Kong people to distinguish themselves

\footnotetext{
7. Ngok Ma, "Hong Kong's Democrats Divide," art. cit.

8. Karita Kan, "Occupy Central and Constitutional Reform in Hong Kong," China Perspectives, No. 2013/3, pp. 73-78.

9. Ngok Ma, "Hong Kong's Democrats Divide," art. cit
} 


\begin{tabular}{|c|c|c|c|c|}
\hline Name & $\begin{array}{c}\text { Established } \\
\text { Year }\end{array}$ & $\begin{array}{l}\text { Key Founder } \\
\text { (Origins) }\end{array}$ & $\begin{array}{l}\text { Core Political } \\
\text { Advocacies }\end{array}$ & $\begin{array}{l}\text { Resistance } \\
\text { Tactics }\end{array}$ \\
\hline Neo Democrats & 2010 & $\begin{array}{c}\text { Gary Fan } \\
\text { (former DP member) }\end{array}$ & $\begin{array}{l}\text { Reforming the Basic Law } \\
\text { and fighting for genuine } \\
\text { universal suffrage }\end{array}$ & $\begin{array}{l}\text { Pursuing non-violent strategies and } \\
\text { rejecting violent clashes }\end{array}$ \\
\hline Proletariat Political Institute & 2011 & $\begin{array}{l}\text { Wong Yuk-man } \\
\text { (former president of LSD and } \\
\text { legislator of People Power) }\end{array}$ & $\begin{array}{l}\text { Devising a Basic Law } \\
\text { by all people }\end{array}$ & $\begin{array}{l}\text { Supporting radical action against } \\
\text { the existing political system }\end{array}$ \\
\hline Civic Passion & 2012 & $\begin{array}{c}\text { Wong Yeung-tat } \\
\text { (former election representative } \\
\text { of People Power) }\end{array}$ & $\begin{array}{l}\text { Advocating independence against } \\
\text { mainlandisation }\end{array}$ & $\begin{array}{l}\text { Supporting radical action with the } \\
\text { principle of no injuries and arrest }\end{array}$ \\
\hline Hong Kong Resurgence & 2014 & $\begin{array}{l}\text { Chin Wan-kan } \\
\text { (author of Hong Kong } \\
\text { as a City-state) }\end{array}$ & $\begin{array}{l}\text { Supporting the principle of "One } \\
\text { Country, Two Systems" and } \\
\text { reforming the Basic Law }\end{array}$ & $\begin{array}{l}\text { Advocating persistent violent and } \\
\text { non-violent resistance }\end{array}$ \\
\hline Youngspiration & 2015 & $\begin{array}{l}\text { Baggio Leung } \\
\text { (participant in the Umbrella } \\
\text { Movement) }\end{array}$ & $\begin{array}{l}\text { Advocating self-determination } \\
\text { and putting "independence" } \\
\text { as one of the options }\end{array}$ & $\begin{array}{l}\text { Supporting diversified } \\
\text { resistance tactics }\end{array}$ \\
\hline Hong Kong Indigenous & 2015 & $\begin{array}{l}\text { Edward Leung } \\
\text { (participant in the Umbrella } \\
\text { Movement) }\end{array}$ & $\begin{array}{l}\text { Advocating independence } \\
\text { to resist political control }\end{array}$ & $\begin{array}{l}\text { Advocating the use of force } \\
\text { to prevent violence } \\
\text { with the authorities }\end{array}$ \\
\hline Hong Kong National Party & 2016 & $\begin{array}{l}\text { Chan Ho-tin } \\
\text { (participant in the Umbrella } \\
\text { Movement) }\end{array}$ & $\begin{array}{l}\text { Establishing a "Republic of } \\
\text { Hong Kong" to curb intervention } \\
\text { by China }\end{array}$ & $\begin{array}{l}\text { Supporting both non-violent and } \\
\text { violent actions }\end{array}$ \\
\hline
\end{tabular}

Source: author's analysis; data adapted from "Bentupai ju xietiao cheng geyou fengong xuanzhan chang zijue xuezhe liao duobaijushang" (Localist groups reject co-ordination in election and claim there is a division of work. Scholar expects a group fragmentation), Ming Pao, 9 April 2016,

http://news.mingpao.com/pns/dailynews/web_tc/article/20160409/s00002/1460139470897 (accessed on 16 April 2016).

from mainlanders. Hong Kong people have been dealing with the "China factor" for more than a decade. More people are worried that existing mainlandHong Kong integration actually provides more opportunity for Beijing to exercise political control over Hong Kong, resulting in the loss of local identity. Also, mainland visitors have shown a strong interest in basic necessities such as milk powder, drinks, and food, believing that Hong Kong products are subject to better quality control than in the mainland. This has led to temporary shortages in several daily necessities, and the competition for daily products between mainland visitors and Hong Kong residents has become politically sensitive. ${ }^{(10)}$ Negative feelings against mainlanders and the Beijing government have contributed to an increasingly strong "anti-China" sentiment.

Scholar Chin Wan-kan published a book entitled Hong Kong as a Citystate, advocating that Hong Kong "forget China and put Hong Kong first," free itself from Beijing's political control, and differentiate itself from the mainland. His discourse gained myriad supporters and became the foundation for localism in Hong Kong. ${ }^{(11)}$ Consequently, some localist groups started establishing and organising a series of campaigns against mainlanders and the Chinese government. For instance, in February 2012, Internet users raised HK\$100,000 in less than a week to finance a full-page "anti-locust" advertisement entitled "Hong Kong people have had enough," pouring sarcasm on mainlanders' use of public resources such as public hospitals and schools. In February 2014, around 100 localist activists held "anti-locust" protests urging mainland tourists to "go back to China." (12)
Originally, public attention toward localist campaigns was not very high as mainstream pan-democrats seldom support this sort of advocacy. The key turning point was the Umbrella Movement in 2014. The failure of the campaign indicated that the Beijing government was not interested in offering real democracy to Hong Kong people and that its only aim was to control Hong Kong, disappointing a large number of people, as evidenced by a drop in trust toward the Beijing government: in late 2008, the year of the Beijing Olympics, $53.1 \%$ of respondents trusted the Beijing government, with only $14.4 \%$ not trusting it, while by the end of 2015, about $40 \%$ did not trust it, with only $35.2 \%$ trusting it. ${ }^{(13)}$ This disappointment further led to reflection on the existing "One Country, Two Systems" policy and resistance strategies. Some people also attributed the failure of campaigns to the leadership of the pan-democratic parties and believed that shifting to "localism," and thereby advocating new tactics and objectives, was the only way out. Hong Kong has therefore developed an increasing number of discourses that mention the future of

10. Ngok Ma, "The Rise of 'Anti-China' Sentiments in Hong Kong and the 2012 Legislative Council Elections," China Review, Vol. 15, No. 1, 2015, pp. 39-66.

11. Danny Mok and Gary Cheung, "Hong Kong's 'Godfather of Localism' Horace Chin Set to Lose Job at Lingnan University," South China Morning Post, 13 April 2015.

12. Jeffie Lam, "Is the Rise of Localism a Threat to Hong Kong's Cosmopolitan Values?", South China Morning Post, 2 June 2015

13. Public Opinion Program, HKU, "On the Whole, Do You Trust the Beijing Central Government? (Halfyearly Average)," https://www.hkupop.hku.hk/chinese/popexpress/trust/trustchigov/halfyr/datatables.html (accessed on 16 April 2016). 
Hong Kong, ranging from Hong Kong Nationalism, which advocates independence, to Reforming Hong Kong, which urges the defence of local interests.

In general, "localism" is a term for a group with a high sense of anti-China sentiment and calling for either curbs on Beijing's intervention or independence for Hong Kong. ${ }^{(14)}$ Indeed, localists advocate different strategies of either remaining non-violent or adopting radicalism. Soft-liners such as the Neo Democrats have organised protests to urge reform of the Basic Law and for Hong Kong people to come first in the allocation of resources. Hardliners such as Hong Kong Indigenous and Civic Passion have agreed to adopt violent clashes with the authorities and mainlanders. They also see claiming independence is a way of forcing the Chinese government to give genuine universal suffrage to Hong Kong. Furthermore, some of them, such as the Hong Kong National Party, have advocated establishing a "Republic of Hong Kong" to take back sovereignty from China (see Table 1).

\section{Differences between traditional pan- democratic parties and localist groups}

Although both traditional pan-democratic parties and localist groups demand democratic reform and oppose political control by China, they have different aims and tactics.

\section{Conflicting identities: Chinese versus Hongkongers}

To begin with, most traditional pan-democratic parties, especially the older members, have a strong Chinese identity while the localists only identify with Hong Kong. Based on their historical connection, the position of the traditional pan-democratic parties is perhaps representative of political sentiments toward China. In terms of "anti-China" explanations, the democrats claim that they are "patriotic" as they supported the reversion of Hong Kong's sovereignty from Britain to China, and have a strong commitment to China's political, social, and economic development. Many traditional democrats identify with "cultural, ethnic, and historic" China rather than the CCP regime. ${ }^{(15)}$

But localists have a strong identification with Hong Kong. Many of them take a more critical attitude towards mainlandisation and the Beijing government and emphasise that Hong Kong people are responsible for protecting the core values and interests of Hong Kong only. In the face of rising political intervention by China, they are sceptical of the "One Country, Two Systems" principle because it cannot eliminate control by Beijing and separate the mainland and Hong Kong. From the localist perspective, the Chinese government is attempting to invade Hong Kong and weaken Hong Kong's identity. ${ }^{(16)}$ This makes localists claim that they are protecting local identity and showing hostility towards the Chinese government and mainlanders. They believe that Hong Kong people should resist intervention by China and social disruption by mainland visitors. In fact, under the atmosphere of heightened anti-China sentiment, a recent survey in 2015 showed that an increasing number of respondents (40.2\%) identified themselves as "Hongkongers" while identification as "Chinese" declined to 18.1\%. This is compared with the survey in 2008, when the percentage of Hong Kong people who identified as "Chinese" peaked at $34.4 \%$, while those identifying as "Hongkongers" stood at 21.8\%. (17) This phenomenon is most obvious among the youth. In terms of age group, $44.4 \%$ of respondents aged 18 to 35 identified themselves as Hongkongers while only $4.2 \%$ classified themselves as "Chinese." (18)

\section{Attitude towards democracy in China: Assistance versus ignorance}

The traditional pan-democrats have long advocated the belief that Hong Kong and China are closely related and that people in Hong Kong have a responsibility to assist in building a "democratic China." They emphasise that they object only to the one-party dictatorship of the CCP, human right conditions, and the CCP's intervention in Hong Kong. To some of them, the political movement in Hong Kong is part of larger movements in China, so Hong Kong should make use of its political freedom to help mainland activists fight rights abuse and promote political reform. The Tiananmen Incident candlelight vigils are typical examples, and the organisers, who mostly come from the pan-democratic camp, emphasise their strong identification with Chinese during the campaigns and advocate that "Hong Kong can get democratic development after China becomes democratised." (19)

Localists have a strong objection to this argument. Newly established associations claim that as Hong Kong is a separate political entity, people should focus on local problems and Hong Kong's future, and distance themselves from the democracy movement in China. Civic Passion member Cheng Chung-tai, for instance, stresses that "the assumption that Hong Kong would have no democracy unless China is democratized is fundamentally flawed and such logic has been poisoning for long." Hong Kong people don't need to deal with the democratic development of China. (20) Due to dissatisfaction with "patriotism," the University of Hong Kong's student union and student unions from other local universities held forums discussing Hong Kong's future while Civic Passion organised its own rallies in five locations on the night of 4 June 2016, becoming alternative events. (21) For many of them, the meaning of June 4 is a reminder of the nature of an authoritarian regime that killed its own people, and more importantly, an opportunity to re-consider the future of Hong Kong. This marks an important difference between the two camps. The traditional democrats identify relatively strongly with China, and only oppose the one-party dictatorship while expressing strong sympathy for Chinese people. Localists, however, regard the CCP regime and mainlanders as major roots of Hong Kong's problems. For them, the CCP's political intervention is the primary reason for the slow pace of development of democracy and autonomy in Hong Kong.

14. Joyce Ng and Jeffie Lam, "Localist Group in Mong Kok Violence Unlikely to Make Headway in Hong Kong Political Area," South China Morning Post, 11 February 2016.

15. Jeffie Lam, "Is the Rise of Localism a Threat to Hong Kong's Cosmopolitan Values?", art. cit.

16. "Violent Unrest in Hong Kong Suggests a Need for Political Cures," The Economist, 13 February 2016, www.economist.com/news/leaders/21692880-violent-unrest-hong-kong-suggests-needpolitical-cures-wounded-society (accessed on 16 April 2016).

17. Public Opinion Poll, HKU, "You Would Identity Yourself as a Hongkonger/Chinese/Chinese in Hong Kong/Hongkonger in China (Half-yearly Average)," https://www.hkupop.hku.hk/chinese/popexpress/ethnic/eidentity/halfyr/datatables.html (accessed on 16 April 2016).

18. "Zhongcezu diaocha qicheng qingnian pan ZhongGang baochi juli" (Survey of Central Policy Unit: $70 \%$ of youngsters agreed with China-Hong Kong separation), Ming Pao, 3 April 2016, http://news.mingpao.com/pns/dailynews/web_tc/article/20160403/s00002/1459619534540 (accessed on 16 April 2016).

19. Jeffie Lam, "Why Hong Kong's Student Leaders are Abandoning June 4 Vigil," South China Morning Post, 4 June 2016

20. Gary Cheung, and Samuel Chan, "Hong Kong's Tiananmen Vigil in Spotlight amid Growth of Localism and Alternative Rallies," South China Morning Post, 5 June 2015.

21. Emily Tsang, Phila Siu, and Shirley Zhao, "Alternative June 4 Events around Hong Kong Call for Change of Approach," South China Morning Post, 5 June 2016 


\section{Resistance tactics: Non-violent versus radical approach}

When facing the growth of political control, traditional democrats have frequently organised various campaigns against "mainlandisation." Most likely due to concern over elections and their public image, they're accustomed to taking a "peaceful, rational, and non-violent" (heping, lixing, feibaoli 和平, 理性, 非暴力) strategy, including organising assemblies, sign-ins, demonstrations, and occupying roads to express their political sentiment. The annual peaceful July 1 handover protests are an example, and they emphasise that a milder approach is the best way to gain society's support and apply pressure on the government.

Although some soft-line localists agree with pursuing a non-violent strategy that is closer to the approach of traditional pan-democrats, some other radical groups accept that "the use of force to prevent violence with the authorities" (yiwu zhibao 以武制暴) is legitimate in order for protesters to protect themselves and the interests of Hong Kong. For them, "managed and predictable" protests have no power for change and have been rendered toothless, so this is the right time to opt for radical rather than mild strategies. (22) Edward Leung and Ray Wong, the founders of Hong Kong Indigenous with 20 members arrested in the violent unrest of the Mong Kok Riot, claim that the Umbrella Movement was a "complete and utter" failure. They believe that when all non-violent protesting attempts have been fully utilised but nothing can be accomplished, it becomes necessary to take a new direction by exercising more radical resistance. ${ }^{(23)}$

\section{Explaining the dynamics between pan- democrats and localists: New partners or enemies?}

Even though both the pan-democratic and localist camps share the common goal of promoting democratic development, the relationship between them remains confrontational with little chance of cooperation. The crux of their differences is the interests of Hong Kong and China. For many localist groups, the mainstream pan-democratic parties have not protected and represented the interests of Hong Kong, as many of them still claim to be "patriotic" by supporting political development and human rights issues in China. Localists believe that Hong Kong people should concentrate on protecting local interests rather than China's. They therefore accuse traditional democrats of being conservative and failing to represent them. ${ }^{(24)}$ Some of them even believe that the traditional pan-democratic camp is blocking the path of democratisation in Hong Kong and regard them as the root cause of the slow pace of democratic reform. Although the two key democratic parties, the DP and $\mathrm{CP}$, are mulling over a plan to incorporate elements of localism into their party manifestos in response to this rising trend, many localists are still sceptical about their aims and methods.

The second important difference is the use of a strategy of resistance. DP vice-chairman Lo Kin-hei, for example, has emphasised that milder methods are still the most powerful against "mainlandisation." In general, pan-democrats agree with the principle of putting Hong Kong first in resource allocation but oppose localism out of concern of advocating xenophobia. They stress that radical localism could turn into fascism, stirring up hatred and discrimination in society. For them, the pursuit of localism should be guided by universal values; otherwise, there is the danger of inciting some Hong Kong people to attack mainlanders. ${ }^{(25)}$ Based on their historical confronta- tion and conflicting tactics, it is inevitable that the chance of co-operation between the two camps is quite low and that tensions remain.

\section{Illustration of government reactions towards localist movements: Repression and co- optation}

In the face of rising localism, both the Chinese and HKSAR governments have taken repressive and co-opting approaches to deal with it. On the one hand, both have adopted a hard line by condemning the pursuits of radical localism and "separatism." Beijing leaders emphasise that a "minority of radicals" has been advocating localism and making use of some incidents to provoke conflict in the relationship between Hong Kong and the mainland. They believe that the radicals' efforts have "seriously hindered social stability" and that the Mong Kok Riot, during which police officers were pelted with bricks and glass bottles and 120 people were injured at the start of the Lunar New Year holiday in 2016, was an example of such violent clashes. ${ }^{(26)}$ Along with the Chinese leaders, Leung Chunying, Hong Kong's Chief Executive, also expressed his strong condemnation of the radical localist movement and promised to better equip police to deal with violent attacks in the future. Some pro-Beijing figures organised a series of petitions and protests to support the police, and some even urged speeding up passage of the national security legislation (Article 23) against "radical localism" and "separatism." (27) Furthermore, a group of pro-Beijing lawyers are calling on Secretary for Justice Rimsky Yuen to formally prosecute groups advocating independence for Hong Kong, as they have allegedly contravened criminal laws prohibiting seditious activities. ${ }^{(28)}$ This has aroused general debate over whether discussing independence is legal or not.

On the other hand, some local government officials and pro-Beijing legislators have adopted a soft-line approach and have attempted to co-opt localism. Financial Secretary John Tsang Chun-wah has put a positive spin on the rise of localism, saying that emotional attachment and a sense of pride are quite common among Hong Kong people. This deep sentiment in Hong Kong can be turned into a strong and constructive force rather than being "merely a selective, negative and even destructive protectionism." (29) Together with him, a few pro-Beijing legislators such as Tsang Yuk-shing, the President of the Legislative Council, have stressed that Hong Kong people

22. Richard Scotford, "Victoria Park Vigil Has Deep and Honourable Roots, But Young People Want Local Focus," Hong Kong Free Press, 2 June 2016, https://www.hongkongfp.com/2016/06/02/victoria-park-vigil-has-deep-and-honourable-roots-but-young-people-want-local-focus (accessed on 10 June 2016).

23. Grace Tsoi and Tessa Wong, "What are Hong Kong's Localists Angry About?", BBC News, 11 February 2016.

24. Joyce Ng, "Hong Kong Student Federation May Quit Pro-democracy Alliance ahead of Tiananmen Vigil," South China Morning Post, 15 April 2015.

25. Jeffie Lam, "Is the Rise of Localism a Threat to Hong Kong's Cosmopolitan Values?", art. cit.

26. Hermina Wong, "Mong Kok Riot Plotted by 'Radical Separatist Organization', says Chinese Foreign Ministry," Hong Kong Free Press, 12 February 2016, https://www.hongkongfp.com/2016/02/12/ mong-kok-riot-plotted-by-radical-separatist-organisation-says-chinese-foreign-ministry (accessed on 16 April 2016)

27. Stuart Lau, Chris Lau, and Christy Leung, "Shots Fired and Bricks Thrown: Hong Kong Tense after Mong Kok Mob Violence on First Day of Lunar New Year," South China Morning Post, 10 February 2016.

28. Owen Fung, "Sedition Laws Could be Unconstitutional, Says Hong Kong National Party: Party Members Hit Back at Lawyers Who Said They Should be Prosecuted," South China Morning Post, 5 May 2016.

29. K.C. Ng, "The Bright Side of Localism: Hong Kong's Finance Minister Sees a Constructive Sense of Pride," South China Morning Post, 27 December 2015 
in general have a strong passion and sense of pride toward their Hong Kong identity, traditions, and culture, but that this sentiment cannot be escalated into tension between Hong Kong and China.

Overall, the position of the Beijing government is quite clear: it tolerates localism in terms of identity, tradition, and culture, but when people's demands shift to "radicalism" in terms of anti-China sentiment, independence, and clashes, the events are harshly condemned and suppressed. In Beijing's approach, this "red line" was adopted to place the interest of the Chinese government as the top consideration.

\section{Conclusion}

Hong Kong has been facing increasingly strong anti-China sentiment together with a strong self-protective mentality in recent years. This sentiment has increased significantly because of rising worries about political control by Beijing, distrust of both the Chinese and HKSAR governments, and social disruption and resource competition from mainland visitors. Emerging literature has long acknowledged the traditional pan-democratic camp as the key actor against "mainlandisation" and political control. But a growing number of Hong Kong people, especially the youth, have become impatient and sceptical towards its discourse and tactics, and some of them have shifted towards the localist camp in the search for new activism and strategies against China's political intervention. This has resulted in the rise of localism in Hong Kong.

Localism is a political movement centred on the defence of Hong Kong's identity and autonomy. The movement contains a number of associations with various directions, but most oppose the increasing political control of the Chinese government. In terms of advocacy, localism emphasises ignoring political conditions in China with a focus on local issues only, ranging from demands for greater autonomy to independence for Hong Kong. In addition, in terms of resistance tactics, some localists advocate using non-violent means or adopting radicalism that is clearly different from the traditional pan-democrats. This localist sentiment reached a peak during the 2016 Legislative Council New Territories East by-election. Edward Leung, the founder of Hong Kong Indigenous, won $15.4 \%$ or 66,524 votes cast in the election, while Alvin Yeung, the winner and a CP member, won
$37.2 \%$, and Holden Chow, a pro-Beijing candidate, won 34.8\%. ${ }^{(30)}$ This strong poll result suggested greater acceptance of the localist movement than previously thought, and that a large number of people supported taking more radical action not only at street level but also within institutions against the authorities. For a youngster without any community work and campaign experience, Leung's performance took both the pro-Beijing and pan-democratic camps by surprise. There needs to be reflection on why tens of thousands voted for someone who was involved in violent unrest heavily denounced by the government. It is foreseeable that the political landscape is now divided among pan-democrats, Beijing loyalists, and localists, with the localist camp becoming the "respectable third." (31)

The rise of localism is a warning to the authorities because China-Hong Kong tensions remain unresolved and have even become more confrontational. Ironically, this sense of stronger resistance has resulted in a vicious cycle: Beijing steps up intervention in Hong Kong affairs while society develops stronger anti-China sentiment followed by localism. However, the HKSAR government has not taken any initiative to address the root of the problem, so Hong Kong can be expected to witness more intense clashes like the Mong Kok Riot. With Hong Kong people becoming more supportive of localism, the political gap between China and Hong Kong will widen. There are two possible ways to deal with this situation. On the one hand, the Chinese government could accommodate the dissatisfaction of Hong Kong people by heeding calls for constitutional reform, in particular the introduction of universal suffrage for the Chief Executive and Legislative Council elections, thus narrowing the gap. On the other hand, China could exercise more political intervention to force Hong Kong society closer to Chinese values. No matter which path is selected, it has to be acknowledged that China-Hong Kong relations have entered a new stage that prompts reflection on the future of Hong Kong after the "One Country, Two Systems" policy ends in 2047.

\section{Ying-ho Kwong is a research assistant at the Academy of Hong Kong Studies of The Education University of Hong Kong (yhkwong3@gmail.com).}

Manuscript accepted on 29 June 2016.
30. Chris Lau, "Beyond the By-election: Hong Kong Young Fuel Rise of Localism at City's Universities," South China Morning Post, 3 March 2016.

31. "Localism is Becoming a Force to be Reckoned With in Hong Kong Politics," South China Morning Post, 29 February 2016. 